Open Access

\title{
The impact of agricultural cooperatives membership on the wellbeing of smallholder farmers: empirical evidence from eastern Ethiopia
}

\author{
Musa Hasen Ahmed ${ }^{*}$ and Hiwot Mekonnen Mesfin
}

* Correspondence: musahasen@gmail.com

School of Agricultural Economics and Agribusiness, Haramaya University, P. O. Box 95, Dire Dawa, Ethiopia

\begin{abstract}
This study evaluated the impact of agricultural cooperative membership on the wellbeing of smallholder farmers using cross-sectional data collected from the eastern part of Ethiopia. Using consumption per adult equivalent as a wellbeing indicator, we measured the impact of agricultural cooperative membership by implementing propensity score matching and endogenous switching regression estimation techniques. Both estimation methods indicate that joining agricultural cooperatives has a positive impact on the wellbeing of smallholder farmers. Furthermore, the analysis also indicates that agricultural cooperative membership has a heterogeneous impact on wellbeing among its members.
\end{abstract}

Keywords: Agricultural cooperatives, Impact evaluation, Wellbeing, PSM, Endogenous treatment, Ethiopia

\section{Background}

Except Africa, all developing regions of the world have achieved the Millennium Development Goal of reducing poverty by half between 1990 and 2015 (UN 2015). As most of Africa's poor depend largely on agriculture for their livelihoods (IFAD 2011), improving the productivity, profitability, and sustainability of the agricultural sector is argued to be the main pathway out of poverty in the continent (Christiaensen et al. 2011; Asfaw et al. 2012; Dawson et al. 2016). In spite of this fact, agricultural sector growth in Africa has been lagging (Diao et al. 2012). Particularly the agricultural productivity in Sub Saharan Africa (SSA) remains stagnant (Tittonell and Giller 2013). Over the past four decades, agricultural productivity growth in SSA averaged only $2.4 \%$ while the productivity of the rest of the developing world improved by $4 \%$ (Dzanku et al. 2015).

Ethiopia is among the countries in this region where agriculture plays a vital role in the economy. In the country, agriculture accounts for $40.2 \%$ of GDP, $80 \%$ of employment, and 70\% of export earnings (UNDP 2015). About $85 \%$ of its population live in rural areas and depend on agriculture for necessities and as a source of employment (Negatu et al. 2016). Therefore, the performance of this sector determines the fate of the economy of the country. Nonetheless, smallholder farmers who are illiterate, living on the threshold between subsistence and poverty, dominate the sector. Their

(c) The Author(s). 2017 Open Access This article is distributed under the terms of the Creative Commons Attribution 4.0 International License (http://creativecommons.org/licenses/by/4.0/), which permits unrestricted use, distribution, and reproduction in any medium provided you give appropriate credit to the original author(s) and the source, provide a link to the Creative Commons license, and indicate if changes were made. 
production system depends on outdated technologies coupled with lack of access to credit, market information, improved technologies, functioning markets (for inputs, outputs, finance, consumer goods, and services, etc.), and other infrastructure (Gebremedhin et al. 2009; Alene and Hassan 2006; Pender and Gebremedhin 2007). Farmers can overcome those problems by acting cooperatively to obtain collective strength that they do not have individually, and in doing so, they find the pathway out of poverty and powerlessness (Birchall and Simmons 2009; Bibby and Shaw 2005). Hence, they need to get organized and cooperatives are an ideal, member-owned, business organization as it offers the institutional framework through which members control both production and marketing activities (Davis 2008).

According to OCDC (2007), cooperatives are the only form of business organization that addresses fully all the economic, democratic, and social dimensions of poverty reduction ${ }^{1}$ simultaneously. Especially, an agricultural cooperative is widely considered as a vital foundation that can help smallholder farmers to overcome the constraints that hinder them from taking advantages of their business as it empowers economically weak farmers by enhancing their collective bargaining power and thereby reduces the risks that they face in the market (Woldu et al. 2013). Most importantly, the role of agricultural cooperatives is very significant in SSA where farms are fragmented over vast and remote rural areas (Wanyama et al. 2009).

Several empirical studies show that agricultural cooperatives improve farm productivity through their influence on the adoption of productivity-enhancing technologies (Spielman et al. 2010; Francesconi and Heerink 2011; Abebaw and Haile 2013) and by improving farm productivity (Abate et al. 2014; Francesconi and Ruben 2012). For instance, in Ethiopia, cooperatives are actively involved in the dissemination of agricultural inputs and about 56\% of chemical fertilizers were provided by cooperatives in the 2010 production season (Matsumoto and Yamano 2010). Cooperatives can also provide credit services to member farmers that ease production constraints (Tefera et al. 2016). This improvement in agricultural productivity is important for enhancing farmer livelihood, reducing rural poverty, and increasing food security (Shiferaw et al. 2014; Zeng et al. 2015; Asfaw et al. 2012; Kassie et al. 2011; Becerril and Abdulai 2010; Alene et al. 2009; Minten and Barrett 2008; Evenson and Gollin 2003).

Several studies also indicate that cooperative membership improves the commercialization behavior of smallholder farmers (Bernard and Spielman 2009; Markelova and Mwangi 2010). Commercialization improves farm productivity and farm income at microlevel, and it improves food security and allocative efficiency at macro level (Timmer 1997). In addition to this, cooperatives can also reduce transaction costs and information asymmetry by strengthening farmers' negotiation ability (Hellin et al. 2009; Trebbin 2014). This will, in turn, increase the income of farmers (members) through their bargaining power, which increases the price of the product they produced and lowers the costs of purchased inputs. Furthermore, more inclusive cooperatives play a strong social role in improving gender relations and helping women create safe spaces to build their social solidarity and problem-solving capacity, particularly in all-female cooperatives (Baden and Pionetti 2011).

Different studies (e.g. Leistritz 2004; Wanyama et al. 2008; Getnet and Anullo 2012; Ito et al. 2012; Verhofstadt and Maertens 2014) also confirm the role of cooperatives in poverty reduction and in improving the livelihood of smallholder farmers. However, 
there are also cases where collective actions did not improve farmers' situation (Poulton et al. 2010). Therefore, more research is required to show the role of agricultural cooperatives and to indicate what really works under which conditions. Hence, this paper aims to identify factors that influence farmers' decisions to join agricultural cooperatives and estimates the impact of agricultural cooperative membership on the welfare ${ }^{2}$ of smallholder farmers of eastern Ethiopia.

The present paper contributes to the growing literature on the role of agricultural cooperatives in three major directions. First, we provide insights into the determinants of agricultural cooperative membership. Therefore, this study allows us to draw implications on cooperative inclusiveness. Second, we evaluate the impact of agricultural cooperatives on the welfare of smallholder farmers quantitatively. Third, in our evaluation of these impacts, we examine if agricultural cooperative membership has a heterogeneous impact on wellbeing among its members. Examining the heterogeneous treatment effects of cooperative membership allows to understand how cooperatives can be more effective in improving the wellbeing of rural community (Verhofstadt and Maertens 2014).

\section{Cooperatives in Ethiopia}

Traditional forms of associations such as iqub, a rotating savings and credit association; work groups such as wonfel and debo; and idir, which raise funds that will be used during emergencies, have a long history in Ethiopia (Abebaw and Haile 2013). However, the first formal cooperative organization was established in Ethiopia around the 1950s (Kodama 2007). Since then, three distinct periods of cooperative movement were observed in the country: cooperative movement during the Emperor period, the Socialist period, and the EPRDF. ${ }^{3}$

The modern cooperative movement was started in the Emperor period under Farm Workers' Cooperatives Decree (Cooperatives Decree No. 44/1960) primarily to solve unemployment problems of retired workers (Emana 2009). However, the voluntary and open membership principle of the cooperatives were not fully practiced in this era. As a person was required to have land to be a member of cooperatives, the feudal land tenure system excluded the peasant farmers from joining cooperatives. Lack of credit facilities and trained manpower were also among the most important constraints which cooperative movement faced at that time. It was during this time that agricultural cooperatives were also started to produce commercial and industrial crops (Abate et al. 2014). Few cooperatives were also engaged in producing industrial crops for export markets, and their members were mostly large landholders (Lemma 2008).

After the overthrow of the Emperor regime in 1974, the Socialist government (1974-1991) that viewed cooperatives as a key instrument to build a socialist economy pursued the cooperative agenda more aggressively to ensure equitable resource mobilization and distribution in the country (Emana 2009). The regime also issued a new cooperative proclamation (Proclamation No. 138/1978). The roles of cooperatives during this period were completely different from those of Western-type cooperatives as they were based on the socialist principles. Compared with the Emperor Regime, the types and numbers of cooperatives increased (Dorsey and Assefa 2005). Mandatory membership and production quotas were among the features of the cooperatives (Spielman 2008). The regime had made cooperatives a platform for conducting political agitation by 
ignoring their basic principle. With the downfall of the socialist regime in May 1991, some of these cooperatives were looted and vandalized for their assets (Rahmato 1994) and dissolved in such a disorderly manner that twisted an eternal suspicion and mistrust of cooperatives, the stigma of which is haunting cooperatives until today (Emana 2009).

Cooperatives did not get any policy attention by EPRDF, the incumbent government, between 1991 and 1993 who came to power in 1991. Since 1994, the government has made efforts to promote a new generation of cooperatives that differ from their predecessors and issued a new cooperative proclamation in 1994 (Proclamation No. 85/1994) which incorporated universally accepted principles of cooperatives. According to this proclamation, cooperatives are independent entities organized to promote common socioeconomic interests of their members (FDRE 1994). The Federal Cooperative Commission (FCC), later named as the Federal Cooperatives Agency (FCA), was established to manage the proper implementation of cooperatives' legislation and to devise policies and legal measures consistent with international conventions on cooperatives (Bernard et al. 2010). The efforts of FCA have resulted in considerable growth in both the number of agricultural cooperatives and the services they provide to their members (Abate et al. 2014). In 2012, there were 43,256 registered primary cooperatives (agricultural cooperatives accounts for $26.5 \%$ of them) with 6.5 million members (of which $21.5 \%$ are female) (Bernard et al. 2013). According to FCA, the number of primary agricultural cooperatives increased from 6825 in 2008 to 15,568 in 2014 (FCA 2015).

\section{Methods}

\section{Description of the study area}

This study was undertaken in the eastern part of Ethiopia particularly in East Hararge zone of Oromia region. The zone is geographically located between $7^{\circ} 32^{\prime}-9^{\circ} 44^{\prime}$ North latitude and $41^{\circ} 10^{\prime}-43^{\circ} 16^{\prime}$ East longitudes with a total area of $24,247.66 \mathrm{~km}^{2}$. The zone is classified into three major climatic categories. These are temperate tropical high lands, semi-temperate, and semi-arid, and they cover 11.4, 26.4, and $62.2 \%$ of the area of the zone, respectively. Central Statistic Agency (CSA) (2013) indicates the population of the zone to reach 3,286,338 in 2014 from which 2,982,533 are residents of rural areas. There are 19 districts in this zone, and three districts, namely Babile, Fedis, and Gursum, are selected for this study.

Babile district has a total area of $3169.06 \mathrm{~km}^{2}$. It is classified into weynadega $a^{4}$ and kola agro-climatic zones, covering about 10 and $90 \%$ of the total area of the district, respectively. Fedis district, on the other hand, lies between $8^{\circ} 52^{\prime}$ and $9^{\circ} 14^{\prime} \mathrm{N}$ latitude and $42^{\circ} 02^{\prime}$ and $42^{\circ} 19^{\prime}$ longitude. About $39 \%$ of this district is in Weynadega agroecology, and the remaining $61 \%$ of the total area of the district is Kola. Gursum district lies between $9^{\circ} 07^{\prime}$ and $9^{\circ} 32^{\prime} \mathrm{N}$ latitude and $42^{\circ} 17^{\prime}$ and $42^{\circ} 38^{\prime}$ E longitude with a total area of $967.31 \mathrm{~km}^{2}$. It is classified into dega, Weynadega, and Kola zones, covering about 15, 35, and 50\% of the total area of the district, respectively. CSA (2013) predicted the population of Babile district to reach 115,229 in 2015 whereas the population of Fedis and Gursum is expected to reach 183,296 and 135,532, respectively. Agriculture is the source of income in the study area. The main cereal crops produced in those districts are sorghum, maize, and oat. Pulses and oilseeds such as horse bean, field peas, 
lentils, groundnut, and linseeds are also produced as cash crops. Besides, chat ${ }^{5}$ and coffee are the two permanent cash crops in the district (Fig. 1).

\section{Sampling techniques and sample size}

If a population from which a sample is to be drawn constitute a heterogeneous group (for our case, members and nonmembers of agricultural cooperatives), stratified sampling is applied. The main advantages of stratified sampling are (i) more reliable information can be obtained from the same sample size if the population is stratified than from the population as a whole and (ii) comparisons between the two groups are easy as a separate but similar survey is done in each group.

Hence, a multi-stage stratifying sampling technique was used to draw an appropriate sample for this study. In the first stage, three districts, namely Babile, Fedis, and Gursum, were selected. In the second stage, 15 rural kebeles $^{6}$ were selected from the selected district proportional to the size of farm households. Accordingly, seven kebeles from Babile, four from Fedis, and four from Gursum were selected randomly. Following this, a list of household heads was obtained from the district office and then households in each district were categorized into agricultural cooperative member and nonmember. Finally, a total of 250 household heads (121 members and 129 nonmembers) were selected from the selected rural kebeles.

\section{Methods of data analysis}

We used both descriptive and econometric tools to analyze the empirical data collected for this study. Descriptive statistics such as mean, standard deviation, range, frequency, and percentage were applied to describe the characteristics of the respondents. In the econometric part, we used propensity score matching and endogenous switching regression models to quantify important empirical results.

\section{Measuring welfare}

Welfare can be measured either from income or expenditure perspectives. However, it is advised to measure welfare based on expenditure in less developed countries such as Ethiopia. This is because household's income is hard to measure in less developed countries as much of it comes from self-employment. Besides, income fluctuates in the

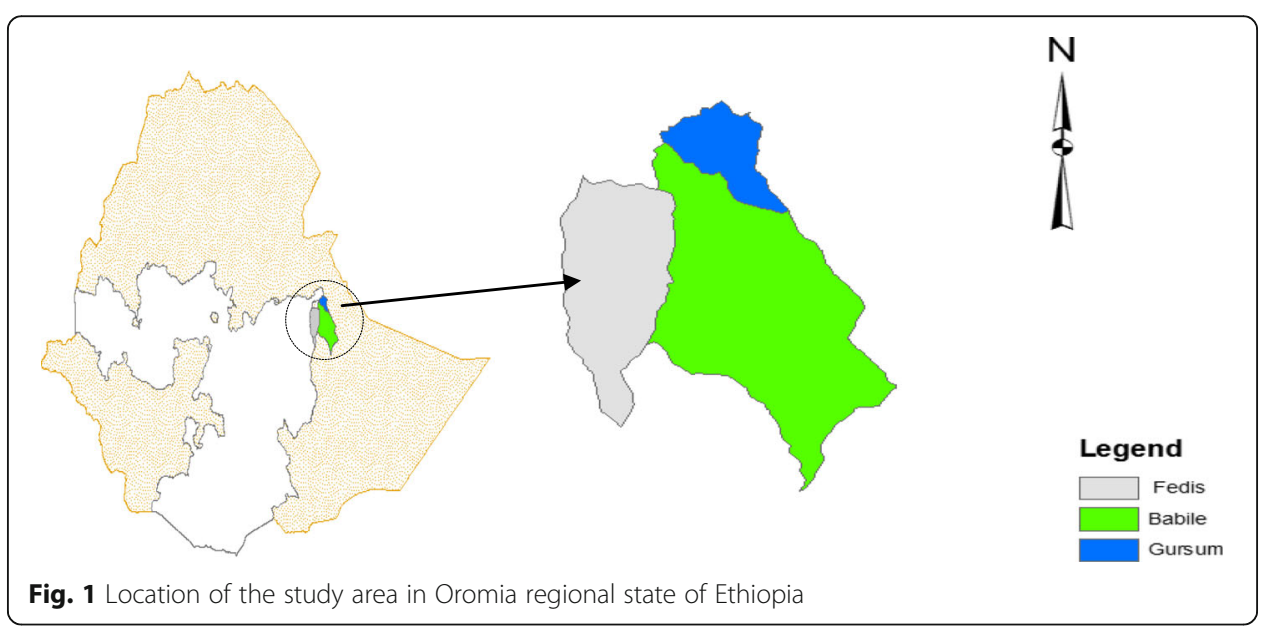


course of one's lifetime, whereas consumption is relatively less erratic, hence easier to estimate (Haughton and Khandker 2009). Consumption data also have additional information because consumption decisions are related with other household decisions such as nutrition and health (Atkinson 1992; Meyer and Sullivan 2003). Moreover, reports of household income are likely to be understated compared to consumption expenditures (Getahun and Villanger 2015). Therefore, we measured welfare by using consumption expenditure per adult equivalent. To estimate the households' consumption expenditure, we asked our respondents a range of questions on aggregate expenditure on both food and non-food items including those on food, clothing, housing, education, and medical care. The aggregated figure was then re-estimated on a per-adult-per-annum base. Previous research that used consumption per adult equivalent to measure wellbeing in Ethiopia includes Hagos and Mamo (2014), Abro et al. (2014), Bezu et al. (2012), and Alem and Söderbom (2012).

Propensity score matching method

Since cooperative members and nonmembers may not be directly comparable as members may self-select (or be selected) into the program based on initial differences, the mean outcome of the two groups differ even in the absence of the treatment. Therefore, before proceeding to future counterfactuals, initial comparability must be established to avoid initial selection bias (Caliendo and Kopeinig 2008). To deal with this problem, we used the propensity score matching (PSM) technique. This technique helps to adjust for initial differences between member and nonmember groups by matching each member unit to a nonmember unit based on similar observable characteristics by conveniently summarizing the conditional probability of member given pretreatment characteristics (Rosenbaum and Rubin 1983). Therefore, the first step in PSM is to predict the propensity score using a logit model. The mathematical formulation of the logit model is as follows:

$$
P_{i}=\frac{e^{z i}}{1+e^{z i}}
$$

where $P_{i}$ is the probability of joining agricultural cooperatives, $e$ represents the base of natural logarithms $(2.718 \ldots)$, and $Z_{i}$ is a function of $n$-explanatory variables which is also expressed as:

$$
Z_{i}=\beta_{o}+\sum_{i=1}^{n} \beta_{i} X_{i}+U_{i}
$$

where $i=1,2,3 \ldots . . n ; \beta_{o}=$ intercept $\beta_{i}=$ regression coefficients to be estimated, $U_{\mathrm{i}}=\mathrm{a}$ disturbance term, and $X_{\mathrm{i}}=$ a set of observable characteristics.

After predicting the propensity scores, imposing the common support region is the next important step because average treatment effect on treated and on population should only be defined in this region (Caliendo and Kopeinig 2008). The common support region is the area within the minimum and maximum propensity scores of treated (members of the agricultural cooperatives) and comparison groups (nonmembers), respectively, and it is demarcated by cutting off those observations whose propensity scores are smaller than the minimum of the treated group and greater than the maximum of the comparison groups (Caliendo and Kopeinig 2008). This stage is followed by identification of an appropriate matching estimator. Caliendo and 
Kopeinig (2008) listed a number of matching estimators including the nearest neighbor (in which an individual from a comparison group is chosen as a matching partner for a treated individual that is closest in terms of propensity score), radius matching (where an individual from the comparison group is chosen as a matching partner for a treated individual that lies within a given radius), stratification (which compares the outcome within intervals/blocks of propensity scores), and Kernel (a non-parametric matching estimator that uses weighted averages of all individuals in the control group to construct the counterfactual outcome).

The fourth important step in PSM is checking for matching quality whether the matching procedure can balance the distribution of different variables or not. If differences exist, there is an indication of incomplete (unsuccessful) matching and remedial actions are suggested (Caliendo and Kopeinig 2008). If good match is found with the predicted probabilities of participation of households, the next step is to check whether the treatment brought about a difference in the indicators of impact. The average treatment effect on the treated (ATT) is given by the difference in mean outcome of matched members and nonmembers that have common support conditional on the propensity score. The mean impacts of joining agricultural cooperatives will, therefore, be given by:

$$
\tau_{i}=Y\left(D_{i}=1\right)-Y\left(D_{i}=0\right)
$$

where $\tau_{i}$ is treatment effect, $Y$ is the outcome, and $D_{i}$ is a dummy whether household $i$ has got the treatment or not. However, one should note that $Y\left(D_{i}=1\right)$ and $Y\left(D_{i}=0\right)$ cannot be observed for the same household at the same time. Due to this fact, estimating individual treatment effect $\tau_{i}$ is not possible and one has to shift to estimating the average treatment effects of the population rather than the individual one. Most commonly used average treatment effect estimation is the ATT, and specified as:

$$
\tau_{A T T}=E(I \mid D=1)=E[Y(1) \mid D=1]-E[Y(0) \mid D=1]
$$

As the counterfactual mean for those being treated, $E[Y(0) \mid D=1]$ is not observed, one has to choose a proper substitute for it in order to estimate the ATT. By rearranging and subtracting $E[Y(0) \mid D=0]$ from both sides, one can get the following specification for ATT.

$$
\begin{aligned}
E[Y(1) \mid D & =1]-E[Y(0) \mid D=1]-E[Y(0) \mid D=0] \\
& =\tau_{A T T}+E[Y(0) \mid D=1]-E[Y(0) \mid D=0]
\end{aligned}
$$

Both terms on the left hand side are observable, and ATT can be identified, if and only if $E[Y(0) \mid D=1-E[Y(0) \mid D=0]=0]$, i.e., when there is no self selection bias. If there is selection bias, matching estimators are not robust (Rosenbaum 2002). To address this matter, we took several measures. First, following the work of Abebaw and Haile (2013), we included several covariates in logit model specification to reduce bias, which could appear due to omitted variables.

Secondly, we apply the bounding approach (Rosenbaum 2002) to check the sensitivity of the estimated results to hidden bias. ${ }^{7}$ In addition, following the works of Cunguara and Darnhofer (2011) and Abebaw and Haile (2013), we conducted what is referred to as a placebo regression ${ }^{8}$ (Imbens and Woolridge 2009) to assert the unconfoundedness assumption that all variables that need to be adjusted for are observed and included in 
the logit model. In this analysis, an OLS regression was estimated with the same covariates used in the estimation of the propensity score, but with a different dependent variable, walking distance to the nearest hospital. This dependent variable is known a priori not to be caused by agricultural cooperative membership. If the coefficient of agricultural cooperative is significantly different from 0 , then there are omitted variables that are correlated with agricultural cooperative membership. Otherwise, the unconfoundedness assumption can be maintained and a causal interpretation of the results is reasonable. The results of the placebo regression (Table 8 in the "Appendix") show that there is no indication of omitted variables that are potentially correlated with agricultural cooperative membership.

Most importantly, we also implemented the endogenous switching regression (ESR) model to check the consistency of the PSM result to control for selection bias. This model also helps to check whether the welfare impacts of cooperative membership are the same among member households.

\section{Endogenous switching regression model}

If it is expected that agricultural cooperative membership has differential effects on household welfare outcome, different welfare outcome functions for members and nonmembers have to be specified, while at the same time accounting for endogeneity. ${ }^{9}$ This justifies the use of the ESR model that accounts for both endogeneity and sample selection bias (Alene and Manyong 2007; Di Falco et al. 2011; Asfaw et al. 2012).

Defining the selection equation is the first step in the ESR specification. The selection equation for agricultural cooperative membership can be specified as follows:

$$
C_{i}^{*}=\beta X_{i}+v_{i} \text { with } C_{i}=\left\{\begin{array}{cc}
1 & \text { if } C_{\mathrm{i}}^{*}>1 \\
0 & \text { otherwise }
\end{array}\right.
$$

where $C_{i}^{*}$ is the latent variable for joining cooperatives, $C_{i}$ is its observable counterpart, $X_{i}$ are vectors of observed characteristics which determine membership, and $u_{i}$ are random disturbances associated with agricultural cooperative membership. We adopted an endogenous switching regression model of welfare outcome measured as consumption expenditure per adult equivalent where farmers face two regimes (1) to join and (2) not to join agricultural cooperatives specified as follows:

$$
\begin{aligned}
& \text { Regime 1: } \quad Y_{1 i}=\alpha_{1} J_{1 i}+e_{1 i} \quad \text { if } \quad C_{i}=1 \\
& \text { Regime 2: } \quad Y_{2 i}=\alpha_{2} J_{2 i}+e_{2 i} \text { if } \quad C_{i}=0
\end{aligned}
$$

where $Y_{\mathrm{i}}$ is household consumption expenditure per adult equivalent in regimes 1 and 2 and $\mathrm{J}_{\mathrm{i}}$ represents a vector of exogenous variables expected to determine consumption expenditure. The error terms are assumed to have a trivariate normal distribution, with 0 mean and non-singular covariance matrix expressed as:

$$
\operatorname{cov}\left(e_{1 i}, e_{2 i}, u_{i}\right)=\left(\begin{array}{ccc}
\sigma_{e 1}^{2} & \cdot & \sigma_{e 1 u} \\
\cdot & \sigma_{e 2}^{2} & \sigma_{e 2 u} \\
\cdot & \cdot & \sigma_{u}^{2}
\end{array}\right)
$$

where $\sigma_{u}^{2}$ is the variance of the error term in the selection Eq. (6), $\sigma_{e 1}^{2}$ and $\sigma_{e 2}^{2}$ are the variances of the error terms in the outcome functions Eq. (7a) and (7b), and $\sigma_{e 1 u}$ and 
$\sigma_{e 2 u}$ represent the covariance of $\mathrm{u}_{\mathrm{i}} \mathrm{e}_{1 \mathrm{i}}$ and $\mathrm{e}_{2 \mathrm{i}}$. The expected values of $\mathrm{e}_{1 \mathrm{i}}$ and $\mathrm{e}_{2 \mathrm{i}}$ conditional on the sample selection are non-zero:

$$
E\left[e_{1 i} \mid C_{i}=1\right]=\sigma_{e 1 u} \frac{\phi\left(\beta x_{i}\right)}{\Phi\left(\beta x_{i}\right)}=\sigma_{e 1 u} \lambda_{1 i}
$$

and

$$
E\left[e_{2 i} \mid C_{i}=0\right]=\sigma_{e 2 u} \frac{\phi\left(\beta x_{i}\right)}{1-\Phi\left(\beta x_{i}\right)}=\sigma_{e 2 u} \lambda_{2 i}
$$

where $\phi($.$) is the standard normal probability density function, \Phi($.$) the standard normal$ cumulative density function, and $\lambda_{1 i}=\frac{\phi\left(\beta x_{i}\right)}{\Phi\left(\beta x_{i}\right)}$ and $\lambda_{2 i}=\frac{\phi\left(\beta x_{i}\right)}{1-\Phi\left(\beta x_{i}\right)}$.

\section{Definitions of explanatory variables and development of hypothesis}

As presented in Table 5 in the "Appendix", we have included personal, household, socioeconomic, institutional, and geographic location variables in our analysis. The selection of those variables is guided by previous empirical literature (e.g., Bernard et al. 2008; Gebremedhin et al. 2009; Matuschke and Qaim 2009; Wanyama et al. 2009; Ito et al. 2012; Fischer and Qaim 2012; Abebaw and Haile 2013; Bernard et al. 2013; Verhofstadt and Maertens 2014; Mojo et al. 2015; Ma and Abdulai 2016).

Among the personal characteristics of the household head, previous studies (such as Bernard et al. 2008; Bernard and Spielman 2009) indicated that the age of the household head has a positive and significant relationship with cooperative membership while the works of Ito et al. 2012; Abebaw and Haile 2013; and Bernard et al. 2013 confirmed that age has a non linear effect. Educational level of the household head is another personal variable that can determine cooperative membership positively (Bernard and Spielman 2009; Verhofstadt and Maertens 2014; Mojo et al. 2015). As confirmed by Abebaw and Haile (2013), sex of the household head can also influence the membership decision. They indicated that male-headed households are more likely to participate in agricultural cooperatives than female-headed households.

Concerning the socioeconomic variables, Abebaw and Haile (2013) indicated that the position of the household head in the community has a direct relationship with cooperative membership. Previous studies also showed that family size is another variable that affects the membership decision positively (Mojo et al. 2015; (Bernard and Spielman 2009). Empirical results also indicated that participation in off/nonfarm activities can influence cooperative membership positively and significantly (Fischer and Qaim 2012; Abebaw and Haile 2013).

To be a member of cooperatives, earlier studies indicated that farmers' asset ownerships also matter. For instance, size of owned land and livestock holdings are found to have a positive effect on cooperative membership (Mojo et al. 2015; Abebaw and Haile 2013; Francesconi and Heerink 2011). Contrary to this, Verhofstadt and Maertens (2014) indicated that owning more land decreases the likelihood of being a cooperative member whereas others (such as Bernard and Spielman 2009; Ito et al. 2012) showed that both the poorest and the wealthiest farmers are least likely to participate in agricultural cooperatives. 
Several institutional variables can also influence participation in cooperatives. For instance, Fischer and Qaim (2012); Abebaw and Haile (2013); and Verhofstadt and Maertens (2014) have indicated that distance to the nearest road has a negative and significant relationship with households' participation in farmers' groups. Additionally, proximity of the cooperative office has a significant influence indicating the effects of farmers' geographic locations on participation decisions (Mojo et al. 2015).

\section{Results and discussion}

Descriptive statistics

Table 1 presents the summary statistics between agricultural cooperative members and nonmembers. As observed in the table, about $85 \%$ were male-headed household. Age of the total sample respondents ranged from 17 to 80 years with a mean of about 37 years. On average, the sample respondents have been engaged in farming for 20 years and about $64 \%$ of the sample household heads did not attain formal schooling.

The mean family size of the sample households measured in adult equivalent $(\mathrm{AE})^{10}$ was 5.12. On average, sample respondents have 4.4 children who are aged less than 16 . On average, respondents own 1.16 oxen and they own 3.44 units of livestock measured in tropical livestock unit (TLU) which is equivalent with 0.72 TLU per adult equivalent. The size of land owned by the sample respondents ranges from 0.5 to $24 q u x i^{11}$ with an

Table 1 Characteristics of sample respondents

\begin{tabular}{|c|c|c|c|c|c|c|}
\hline \multirow[t]{2}{*}{ Variables } & \multicolumn{2}{|c|}{ Nonmembers } & \multicolumn{2}{|c|}{ Members } & \multicolumn{2}{|c|}{ Combined } \\
\hline & Mean & Std. Err. & Mean & Std. Err. & Mean & Std. Err. \\
\hline Age & 36.48 & 0.98 & 37.91 & 1.17 & 37.17 & 0.76 \\
\hline Sex & 0.84 & 0.03 & 0.87 & 0.03 & 0.85 & 0.02 \\
\hline Education & 0.30 & 0.04 & 0.41 & 0.04 & 0.36 & 0.03 \\
\hline Farming experience & 20.36 & 0.96 & 18.98 & 0.90 & 19.69 & 0.66 \\
\hline Social responsibility & 0.11 & 0.03 & 0.64 & 0.04 & 0.36 & 0.03 \\
\hline Land owned & 7.55 & 0.38 & 8.08 & 0.41 & 7.81 & 0.28 \\
\hline Number of oxen & 0.96 & 0.08 & 1.36 & 0.19 & 1.16 & 0.10 \\
\hline Off/nonfarm activity & 0.09 & 0.02 & 0.24 & 0.04 & 0.16 & 0.02 \\
\hline Market information & 0.84 & 0.03 & 0.79 & 0.04 & 0.82 & 0.03 \\
\hline Market distance & 4.45 & 0.52 & 5.98 & 0.70 & 5.19 & 0.44 \\
\hline Coop office distance & 2.46 & 0.27 & 1.57 & 0.17 & 2.03 & 0.16 \\
\hline Livestock in TLU & 2.94 & 0.19 & 3.99 & 0.73 & 3.45 & 0.37 \\
\hline Family aged delow 16 & 4.47 & 0.31 & 4.34 & 0.23 & 4.40 & 0.20 \\
\hline Family aged above 50 & 0.27 & 0.10 & 0.60 & 0.12 & 0.43 & 0.08 \\
\hline Family size in $\mathrm{AE}$ & 4.99 & 0.25 & 5.26 & 0.21 & 5.12 & 0.16 \\
\hline TLU less oxen & 1.98 & 0.14 & 2.63 & 0.56 & 2.29 & 0.28 \\
\hline TLU per AE & 0.66 & 0.05 & 0.79 & 0.10 & 0.72 & 0.05 \\
\hline Land per AE & 1.79 & 0.12 & 1.78 & 0.12 & 1.79 & 0.09 \\
\hline Babile & 0.60 & 0.04 & 0.55 & 0.05 & 0.58 & 0.03 \\
\hline Gursum & 0.22 & 0.04 & 0.21 & 0.04 & 0.22 & 0.03 \\
\hline Fedis & 0.18 & 0.03 & 0.23 & 0.04 & 0.20 & 0.03 \\
\hline
\end{tabular}


average size of 7.81 quxi, which is equivalent with 1.79 quxi per adult equivalent. Thirty six percent of respondents have a social responsibility such as a security guard (Militia), member of the local administration, and religious or traditional leadership. Sixteen percent of respondents are engaged in non/off farm activities. Out of the total of the respondents, $82 \%$ have access to market information. The sample respondents are, on average, 5.22 and $1.3 \mathrm{~km}$ far from the market and farmers training center, respectively.

\section{Determinants of cooperative membership}

This sub-section presents the result of the logit regression model, which was used to estimate the propensity score for matching the cooperative members with nonmembers. The dependent variable in the logit model is coded as 1 if the household head is a member of agricultural cooperatives and 0 for nonmembers. The model sufficiently fitted the data at the $1 \%$ level $\left(\operatorname{LR} \chi^{2}(14)=103.01\right.$; Prob $\left.>\chi^{2}=0.000\right)$.

The result of the logit model, presented in Table 2, indicated that the position of the head in the society, distance to the nearest market, distance to the cooperative office, size of owned land, and location dummy for Babile districts are the significant variables that determine smallholders' decision to joining agricultural cooperatives.

As expected, the involvement of the household head in social responsibility determines the probability of agricultural cooperative membership significantly. The result is plausible as participation in social responsibility eases access to relevant information about the benefits of agricultural cooperatives. This result is in line with the finding of Abebaw and Haile (2013).

Distance to the nearest market has a positive relationship with cooperative membership, which justifies that farmers located near to a market are less dependent on group activities. In contrast, farmers who are far from the market place may

Table 2 Result of the logit model of factors determining cooperative membership

\begin{tabular}{lcc}
\hline Variables & Coef. & Std. Err. \\
\hline Age & 0.03 & 0.03 \\
Sex & 0.62 & 0.50 \\
Educational & 0.25 & 0.38 \\
Social responsibility & $2.58^{\mathrm{a}}$ & 0.38 \\
Off/nonfarm activity & 0.69 & 0.48 \\
Market distance & $0.07^{\mathrm{b}}$ & 0.03 \\
Farming experience & -0.03 & 0.03 \\
Coop office distance & $-0.16^{\mathrm{c}}$ & 0.09 \\
Land owned & $0.09^{\mathrm{b}}$ & 0.04 \\
Number of oxen & 0.20 & 0.17 \\
Family size in AE & -0.08 & 0.08 \\
TLU less oxen & 0.00 & 0.06 \\
Babile & $-1.39^{\mathrm{a}}$ & 0.49 \\
Gursum & -0.90 & 0.58 \\
Cons & -1.89 & 0.87 \\
\hline a ${ }^{\mathrm{b}}{ }^{\text {, and }}{ }^{\mathrm{c}}$ significant at 1,5, and $10 \%$ probability level, respectively &
\end{tabular}


expect higher returns of cooperatives and are hence more likely to join agricultural cooperatives. This is plausible since farmers located near to the market have better access to markets anyway, so that they are less dependent on agricultural cooperatives. On the other hand, farmers who are distant from the markets face higher transaction costs, which makes cooperative membership more beneficial (Verhofstadt and Maertens 2014). Fischer and Qaim (2012) also obtained the same relationship between distance to the nearest market and probability of agricultural cooperative membership.

The results also indicate that distance to the cooperative office has an inverse relationship with the probability of agricultural cooperative membership. This is justifiable because when the cooperative office is close to the household head, the cost of time and labor that the farmer spends to communicate with cooperative officers will be reduced. Those farmers who are close to the cooperative office will also have more knowledge about the cooperatives and their benefits.

The size of the land holding has a positive and significant effect on the probability of membership. This is reasonable, because larger farms are not only wealthier but also have a higher capacity to expand agricultural production that in turn forces the farmer to join cooperatives to sell the product and to access farm input easily. The result is consistent with the findings of Thorp et al. (2005) and Francesconi and Heerinck (2010) who revealed that the poorest farmers are excluded from agricultural cooperatives. Ito et al. (2012) also vindicated that smallholder farmers opt to self-exclude from participating in agricultural cooperatives if the costs of membership are greater than the returns obtained from membership.

\section{Impact of cooperative membership on consumption per adult equivalent}

After implementing the logit model for cooperative membership, we estimated the propensity scores. The estimated propensity scores for the whole sample range between 0.0174 and 0.9933 with mean score of 0.4797 . The propensity scores for nonmembers vary between 0.0174 and 0.9138 , and for members, they vary between 0.1268 and 0.9933. Thus, the common support region, where the values of propensity scores of both treatment and comparison groups can be found, is given in the range between 0.1268 and 0.9138 . Observations whose propensity scores lie outside this range are dropped from the sample.

Table 3 reports the estimation results for the average treatment effect on the treated (ATT) of the outcome variable using PSM techniques under different matching estimators. The impact estimates indicate that agricultural cooperative membership has a

Table 3 Average treatment effect of cooperative membership under different algorithms

\begin{tabular}{lr}
\hline Matching algorithm & ATT \\
\hline Radius & $0.228^{\mathrm{a}}$ \\
Kernel & $0.197^{\mathrm{c}}$ \\
Nearest neighbor & $0.265^{\mathrm{b}}$ \\
Stratification & $0.176^{\mathrm{c}}$ \\
\hline a $^{\mathrm{b}}$, and ${ }^{\mathrm{c}}$ significant at 1, 5, and 10\% probability level, respectively &
\end{tabular}


positive and significant impact on the welfare of the farmers measured in annual consumption expenditure per adult equivalent. This finding is in line with the results of Ito et (al. 2012) and Verhofstadt and Maertens 2014) who examined the role of agricultural cooperatives on poverty reduction.

Using the nearest neighbor algorithm, cooperative membership was found to have 26.5\% higher consumption per adult equivalent than the nonmember counterfactual. Applying a radius matching algorithm, the result also showed that the members expenditure is $22.8 \%$ higher. Similarly, the stratification algorithm showed that there is a significant difference, amounting to $17.6 \%$, in expenditure per adult equivalent between the two groups.

To check the robustness of our results from PSM findings, we also employed ESR that can control for unobservable selection bias. The result of the full information maximum likelihood estimates of the ESR model is reported in Table 4. The second column presents the estimated coefficients of selection Eq. (6) on joining cooperatives whereas the fourth and sixth column presents the consumption expenditure for households that are and are not members of agricultural cooperatives.

Results from the model show that the estimated coefficient of correlation between the cooperative membership equation and the consumption expenditure function is negative and significantly different from 0 for nonmembers of agricultural cooperatives. The result suggests that individuals who are not members of agricultural cooperatives have less consumption expenditure per adult than a random individual from the sample does. More specifically, the result reveals that if nonmembers had been members of agricultural cooperatives, their consumption per adult equivalent would have been higher. This implies that agricultural

Table 4 Full information maximum likelihood estimates of the switching regression model

\begin{tabular}{|c|c|c|c|c|c|c|}
\hline \multirow[t]{2}{*}{ Variables } & \multicolumn{2}{|c|}{ Selection } & \multicolumn{2}{|c|}{ Nonmembers } & \multicolumn{2}{|l|}{ Members } \\
\hline & Coef & Std. Err. & Coef & Std. Err. & Coef & Std. Err. \\
\hline Constant & -0.781 & -0.781 & $9.495^{\mathrm{a}}$ & 0.229 & $8.904^{\mathrm{a}}$ & 0.247 \\
\hline Age & 0.018 & 0.018 & -0.004 & 0.006 & 0.005 & 0.010 \\
\hline Farming experience & -0.010 & 0.019 & -0.002 & 0.007 & -0.007 & 0.010 \\
\hline Education & 0.273 & 0.242 & 0.039 & 0.086 & $0.161^{c}$ & 0.086 \\
\hline Off/nonfarm activity & & & $0.713 \mathrm{E}-04$ & 0.000 & $0.125 \mathrm{E}-04$ & 0.101 \\
\hline Family aged below 16 & -0.038 & 0.054 & $-0.095^{\mathrm{a}}$ & 0.021 & $-0.062^{\mathrm{a}}$ & 0.011 \\
\hline Family aged above 50 & $0.142^{c}$ & 0.077 & 0.027 & 0.041 & -0.081 & 0.113 \\
\hline TLU per AE & 0.199 & 0.142 & 0.042 & 0.088 & 0.042 & 0.088 \\
\hline land per $\mathrm{AE}$ & 0.109 & 0.112 & $0.059^{c}$ & 0.032 & $0.062^{c}$ & 0.034 \\
\hline Market distance & 0.017 & 0.018 & -0.003 & 0.008 & $-0.015^{c}$ & 0.008 \\
\hline Babile & $-0.782^{b}$ & 0.347 & & & & \\
\hline Gursum & -0.337 & 0.440 & & & & \\
\hline Coop office distance & -0.101 & 0.076 & & & & \\
\hline Social responsibility & $1.693^{\mathrm{a}}$ & 0.238 & & & & \\
\hline SIGMA & & & $0.406^{\mathrm{a}}$ & 0.027 & $0.387^{\mathrm{a}}$ & 0.027 \\
\hline $\mathrm{RHO}$ & & & $-0.423^{b}$ & 0.205 & 0.087 & 0.374 \\
\hline
\end{tabular}

$\mathrm{a}, \mathrm{b}$, and ${ }^{\mathrm{c}}$ significant at 1,5 , and $10 \%$ probability level, respectively 
cooperatives increased household welfare measured in terms of consumption expenditure and supports the findings of the PSM model.

Furthermore, the result also indicates that the impact of cooperative membership on welfare is not the same for all members. In particular, cooperatives improve the welfare for literate members significantly more than that of illiterate members. The result also indicates that cooperatives improve the welfare for members who have more land per adult equivalent significantly more than for members who own smaller sizes of land in adult equivalent. The finding implies that the cooperatives under study are most effective in improving wellbeing among cooperative members with relatively larger landholdings per adult equivalent. Given our finding of the logit results presented in Table 2, this indicates the positive role that the size of owned land has on cooperative membership. Moreover, these findings imply that, even among the members of the cooperatives, those who own larger land per capita are getting the most out of the cooperatives. This might indicate that there is a trade-off between efficiency and equity (or exclusiveness and inclusiveness) in the agricultural cooperatives working in the study area. As emphasized by Tefera et al. (2016), the trade-off between efficiency and equity has become more relevant for agricultural cooperatives in Ethiopia, as cooperatives are transforming into organizations that are more commercial. Our finding is consistent with the work of Verhofstadt and Maertens (2014) who indicated that cooperative membership is not effective for improving welfare for land-poor or near-landless farmers. The impact of cooperatives on welfare is also larger for members who have fewer number of children aged below 16 and who are close to the nearest market.

\section{Conclusions}

This study analyzed the inclusiveness of agricultural cooperatives and evaluated the potential impact of agricultural cooperative membership on household welfare measured by consumption expenditure based on data collected from the eastern part of Ethiopia. The results indicate that cooperative membership favors farm households who have social responsibility with large land holdings and those who are far from markets and close to the cooperative offices. Hence, the agricultural cooperatives in the study area are to some extent exclusive.

We estimated the impact of agricultural cooperative membership by applying propensity score matching and endogenous switching regression methods. This helps to estimate the true welfare effect of agricultural cooperative membership by controlling for the self-selection problem on joining decisions. Our results indicate that agricultural cooperatives are effective in improving the wellbeing of the rural community. The impact estimation from the propensity score matching suggests that agricultural cooperative members have significantly higher consumption per adult equivalent than nonmembers. The result from the endogenous switching regression also confirms that individuals who are not a member of agricultural cooperatives have lower consumption expenditure per adult equivalent than a random individual from the sample would have, and their consumption expenditure would have been higher if they were a member of agricultural cooperatives. 
Furthermore, the analysis also indicates that cooperative membership has a heterogeneous impact on wellbeing among its members. We found that cooperative membership is effective at improving wellbeing for more-educated household heads that have fewer children and a larger land size per capita.

Hence, cooperatives should not be viewed as a sufficient means to target the poorest of the poor farmers. Cooperatives can be considered as an alternative means of improving the wellbeing of the agrarian community. Thus, further promoting, deepening, and supporting cooperatives as appropriate rural organizations is recommended. However, participation into cooperatives could be more pro-poor by avoiding entry barriers in the future. Hence, efforts have to be made to tackle factors that are impeding land-poor households from participating in agricultural cooperatives.

In conclusion, the results of the study provide information to policy makers and other stakeholders on how to improve farmers' participation in agricultural cooperatives. These findings stress the need for appropriate policy formulation and implementation which improves farmers' participation in cooperatives as this is expected to have multiplier effects ranging from farm productivity growth to economic growth and poverty reduction at the macro level.

\section{Endnotes}

${ }^{1}$ To see more regarding the role and potential of cooperatives in poverty reduction, please refer to Simmons and Birchall (2008) and Tefera et al. (2016).

${ }^{2}$ Wellbeing and welfare are used interchangeably.

${ }^{3}$ Ethiopian People's Revolutionary Democratic Front

${ }^{4}$ Dega ecological zone lies between 2300 and $3200 \mathrm{~m}$ altitude with 900$1200 \mathrm{~mm} /$ year of rainfall and average annual temperature of $11.5{ }^{\circ} \mathrm{C}$. Weynadega lies in at an altitude of $1500-2300 / 2400 \mathrm{~m}$ with rainfall of $800-1200 \mathrm{~mm} /$ year and average annual temperature of $20.0-17.5 / 16.0{ }^{\circ} \mathrm{C}$. Kola's altitude is from 500 to $1500 / 1800 \mathrm{~m}$ with rainfall of $200-800 \mathrm{~mm} /$ year and annual temperature of $27.5-20{ }^{\circ} \mathrm{C}$ (MoA 2000).

${ }^{5}$ Chat (Catha edulisor) is an evergreen plant used commonly for mastication and its sympathomimetic actions (Cox and Rampes 2003).

${ }^{6}$ Kebele is the smallest administrative hierarchy in Ethiopia.

${ }^{7}$ Hidden bias arises if there are unobserved variables that affect both participation in cooperatives and the outcome variable of interest (Abebaw and Haile 2013). If there is a hidden bias, matching estimators are not robust (Rosenbaum 2002).

${ }^{8} \mathrm{We}$ thank an anonymous reviewer for bringing this issue to our attention.

${ }^{9}$ Endogeneity problems arise when unobservable characteristics of farmers affect both the decision to be a member of agricultural cooperatives and the welfare outcome, resulting in inconsistent estimates of the impact of agricultural cooperatives on household welfare.

${ }^{10}$ Family size is calculated by converting difference in age and sex of members of the family members using the conversion factor given in Table 7 in Appendix, and Table 6 in Appendix indicates the conversion factor used to compute TLU.

${ }^{11}$ quxi is a local measurement unit equivalent with $1 / 8$ of a hectare. 


\section{Appendix}

Table 5 Description of explanatory variables and hypotheses

\begin{tabular}{|c|c|c|}
\hline Variables & Description & $\begin{array}{l}\text { Expected effect } \\
\text { on membership }\end{array}$ \\
\hline Age & Age of the household head & "+", "-" \\
\hline Sex & $\begin{array}{l}\text { Gender of the household head; } 1 \text { if male and } 0 \\
\text { otherwise }\end{array}$ & "+", "-" \\
\hline Education & $\begin{array}{l}\text { Educational status of household head; } 1 \text { if attended } \\
\text { some form of education } 0 \text { otherwise }\end{array}$ & $"+"$ \\
\hline Farming experience & $\begin{array}{l}\text { Number of years since the household head started } \\
\text { agricultural production }\end{array}$ & $"+"$ \\
\hline Social responsibility & $\begin{array}{l}\text { The position of the household head in the society; } \\
1 \text { if the head has social responsibility and } 0 \text { otherwise }\end{array}$ & $"+"$ \\
\hline Number of oxen & Number of oxen the household owned & $"+"$ \\
\hline Off/nonfarm activity & $\begin{array}{l}\text { Participation in off/nonfarm activity; } 1 \text { if the head } \\
\text { participates in off/nonfarm activities and } 0 \text { otherwise }\end{array}$ & "-" \\
\hline Market distance & $\begin{array}{l}\text { Distance from the respondent's residence to the } \\
\text { nearest market measured in kilometer }\end{array}$ & "-" \\
\hline Market information & $\begin{array}{l}\text { Access to market information; } 1 \text { if the household } \\
\text { head has access } 0 \text { otherwise }\end{array}$ & $"+"$ \\
\hline Coop office distance & $\begin{array}{l}\text { Distance from the respondent's residence to the } \\
\text { cooperative office in kilometer }\end{array}$ & "-" \\
\hline Family aged below 16 & $\begin{array}{l}\text { The numbers of family members of the respondent } \\
\text { who are aged below } 16\end{array}$ & "-" \\
\hline Family aged above 50 & $\begin{array}{l}\text { The numbers of family members of the respondent } \\
\text { who are aged above } 50\end{array}$ & "-" \\
\hline Family size in $\mathrm{AE}$ & Family size expressed in adult equivalent & "-", "+" \\
\hline Livestock in TLU & $\begin{array}{l}\text { Size of livestock the household own measured in } \\
\text { tropical livestock units }\end{array}$ & \\
\hline TLU less oxen & $\begin{array}{l}\text { Size of livestock the household own except the } \\
\text { number of oxen expressed in tropical livestock units }\end{array}$ & $"+"$ \\
\hline TLU per AE & $\begin{array}{l}\text { Size of livestock owned by the household measured in } \\
\text { tropical livestock units expressed per adult equivalent }\end{array}$ & $"+"$ \\
\hline Land owned & Size of land owned by the household measured in quxi & $"+"$ \\
\hline Land per AE & $\begin{array}{l}\text { Size of land owned by the household expressed } \\
\text { in adult equivalent }\end{array}$ & "+" \\
\hline Babile & The household lives in Babile district & "+", "-" \\
\hline Gursum & The household lives in Gursum district & $"+"$ \\
\hline Fedis & The household lives in Fedis district & $"+"$ \\
\hline
\end{tabular}


Table 6 Conversion factors used to estimate tropical livestock unit (TLU) equivalents

\begin{tabular}{lr}
\hline Animal Category & TLU \\
\hline Calf & 0.25 \\
Donkey (young) & 0.35 \\
Weaned Calf & 0.34 \\
Camel & 1.25 \\
Heifer & 0.75 \\
Sheep and goat (adult) & 0.13 \\
Cow and ox & 1.00 \\
Sheep and goat (young) & 0.06 \\
Horse & 1.10 \\
Chicken & 0.013 \\
Donkey (adult) & 0.70 \\
\hline
\end{tabular}

Source: Storck et al. (1991)

Table 7 Conversion factor for computation of adult equivalent

\begin{tabular}{lll}
\hline & \multicolumn{2}{l}{ Adult equivalent } \\
\cline { 2 - 3 } Age group (years) & Male & Female \\
\hline$<10$ & 0.6 & 0.6 \\
$11-13$ & 0.9 & 0.8 \\
$14-16$ & 1 & 0.75 \\
$17-50$ & 1 & 0.75 \\
$>50$ & 1 & 0.7 \\
\hline
\end{tabular}

Source: Storck et al. (1991)

Table 8 Result of the placebo regression

\begin{tabular}{lcc}
\hline Variables & Coef & Std. Err. \\
\hline Cooperative membership & 0.026 & 0.085 \\
Age & $0.137^{\mathrm{a}}$ & 0.005 \\
Sex & -0.095 & 0.102 \\
Education & 0.031 & 0.080 \\
Farming experience & -0.001 & 0.006 \\
Social responsibility & 0.123 & 0.087 \\
Off/nonfarm activity & 0.091 & 0.099 \\
Distance to market & -0.005 & 0.005 \\
Distance to cooperative & 0.008 & 0.017 \\
Land owned & 0.000 & 0.009 \\
Oxen & -0.020 & 0.038 \\
Family size AE & 0.021 & 0.016 \\
TLU less ox & -0.006 & 0.013 \\
Gursum & $-0.216^{c}$ & 0.121 \\
Babile & -0.125 & 0.100 \\
_cons $^{\mathrm{c}}$ and ${ }^{\mathrm{c}}$ significant at 1, 5, and 10\% probability level, respectively & $-1.588^{\mathrm{a}}$ & 0.171 \\
\hline
\end{tabular}

${ }^{a}$ and ${ }^{c}$ significant at 1,5 , and $10 \%$ probability level, respectively 
Abbreviations

ATT: Average treatment effect of the treated; CSA: Central Statistic Agency; ESR: Endogenous switching regression; PSM: Propensity score matching; SSA: Sub Saharan Africa

\section{Acknowledgements}

We are grateful to Haramaya University for funding this research work. We also acknowledge Mr. Kumilachew Alamerie (Ass. Prof. of Agricultural Economics) and anonymous referees for their insightful and valuable comments. Enumerators, sample respondents, and extension staff of the Ministry of Agriculture are also highly appreciated for their efforts that led to the success of this study.

\section{Funding}

Haramaya University financially and logistically supported this research.

\section{Availability of data and materials}

The data that support the findings of this study can be obtained from the authors based on request.

\section{Authors' contributions}

MHA conceptualized the study and performed the data analysis. HMM designed, coordinated, and supervised the household survey. She was also responsible for the interpretation of the model results and write up of the manuscript. Both authors read and approved the final manuscript.

\section{Authors' information}

Mr. Musa Hasen Ahmed is a staff member of the Department of Agricultural Economics at Haramaya University. He has an MSc degree in Agricultural Economics. He has published articles related to productivity analysis, impact evaluation, natural resource valuation, and adoption of agricultural technologies. Ms. Hiwot Mekonnen is a staff member of the School of Agricultural Economics and Agribusiness at Haramaya University. She obtained her BSc in Agricultural Economics and MSc in Rural Development. She has experience in researches related to agricultural technology adoption, value chain analysis, gender mainstreaming, and food security analysis.

\section{Competing interests}

The authors declare that they have no competing interests.

\section{Ethics approval and consent to participate}

Ethical approval and consent to participate is not applicable for our study.

\section{Publisher's Note}

Springer Nature remains neutral with regard to jurisdictional claims in published maps and institutional affiliations.

Received: 6 June 2016 Accepted: 7 March 2017

Published online: 03 April 2017

\section{References}

Abate GT, Francesconi GN, Getnet K (2014) Impact of agricultural cooperatives on Smallholders' technical efficiency: empirical evidence from Ethiopia. Ann Public Coop Econ 85(2):257-286. doi:10.1111/apce.12035

Abebaw D, Haile MG (2013) The impact of cooperatives on agricultural technology adoption: empirical evidence from Ethiopia. Food Policy 38:82-91, http://dx.doi.org/10.1016/j.foodpol.2012.10.003

Abro ZA, Alemu BA, Hanjra MA (2014) Policies for agricultural productivity growth and poverty reduction in rural Ethiopia. World Dev 59:461-474, http://dx.doi.org/10.1016/j.worlddev.2014.01.033

Alem Y, Söderbom M (2012) Household-level consumption in urban Ethiopia: the effects of a large food price shock. World Dev 40(1):146-162, http://dx.doi.org/10.1016/j.worlddev.2011.04.020

Alene AD, Hassan RM (2006) The efficiency of traditional and hybrid maize production in eastern Ethiopia: an extended efficiency decomposition approach. J Afr Econ 15(2):I-xxvii. doi:10.1093/jae/ejl020

Alene AD, Manyong VM (2007) The effects of education on agricultural productivity under traditional and improved technology in northern Nigeria: an endogenous switching regression analysis. Empir Econ 32(1):141-159. doi:10.1007/s00181-006-0076-3

Alene AD, Menkir A, Ajala SO, Badu-Apraku B, Olanrewaju AS, Manyong VM, Ndiaye A (2009) The economic and poverty impacts of maize research in West and Central Africa. Agric Econ 40(5):535-550. doi:10.1111/j.1574-0862.2009.00396.x

Asfaw S, Shiferaw B, Simtowe F, Lipper L (2012) Impact of modern agricultural technologies on smallholder welfare: evidence from Tanzania and Ethiopia. Food Policy 37(3):283-295, http://dx.doi.org/10.1016/j.foodpol.2012.02.013

Atkinson AB (1992) Measuring poverty and differences in family composition. Economica 59:1-16. doi:10.2307/2555062

Baden S, Pionetti C (2011) Women's collective action in agricultural markets: synthesis of preliminary findings from Ethiopia, Mali, and Tanzania. Oxfam Policy Pract Agric Food Land 11(7):70-126, http://www.ingentaconnect.com/ content/oxpp/oppafl/2011/00000011/00000007/art00004

Becerril J, Abdulai A (2010) The impact of improved maize varieties on poverty in Mexico: a propensity score-matching approach. World Dev 38(7):1024-1035, http://dx.doi.org/10.1016/j.worlddev.2009.11.017

Bernard T, Spielman DJ (2009) Reaching the rural poor through rural producer organizations? A study of agricultural marketing cooperatives in Ethiopia. Food Policy 34(1):60-69, http://dx.doi.org/10.1016/j.foodpol.2008.08.001

Bernard T, Taffesse AS, Gabre-Madhin E (2008) Impact of cooperatives on smallholders' commercialization behavior: evidence from Ethiopia. Agric Econ 39(2):147-161. doi:10.1111/j.1574-0862.2008.00324.x

Bernard T, Spielman DJ, SeyoumTaffesse A, Gabre-Madhin EZ (2010) Cooperatives for staple crop marketing: evidence from Ethiopia (Vol. 164). Intl Food Policy Res Inst. https://books.google.com/books?hl=en\&lr=\&id=_ 
vOMNQhT9NcC\&oi=fnd\&pg=PR1\&dq=Bernard, + T.,+Spielman, + D. + J.,+SeyoumTaffesse, + A., $+\% 26$ Gabre-Madhin,, E. + Z.+(2010).+Cooperatives+for+staple+crop+marketing:+Evidence+from+Ethiopia+(Vol.+164).+Intl+Food+Policy+Res +Inst.\&ots=KtM29scceA\&sig=94MvgTeX9my2jqDGYaeXQ1i1yow\#v=onepage\&q\&f=false

Bernard T, Abate GT, Lemma S (2013) Agricultural cooperatives in Ethiopia: results of the 2012 ATA baseline survey. International Food Policy Research Institute, Washington DC, http://citeseerx.ist.psu.edu/viewdoc/download?doi=10 1.1.352.7458\&rep=rep1\&type=pdf

Bezu S, Barrett CB, Holden ST (2012) Does the nonfarm economy offer pathways for upward mobility? Evidence from a panel data study in Ethiopia. World Dev 40(8):1634-1646, http://dx.doi.org/10.1016/j.worlddev.2012.04.019

Bibby A, Shaw L (2005) Making a difference: cooperative solution to global poverty. Cooperative College for the Department of International Development, Manchester

Birchall J, Simmons R (2009) Co-operatives and poverty reduction: evidence from Sri Lanka and Tanzania. Co-op College, Manchester, https:/coopseurope.coop/development/sites/default/files/co-operatives-and-poverty-reduction.pdf

Caliendo M, Kopeinig S (2008) Some practical guidance for the implementation of propensity score matching. J Econ Surv 22(1):31-72. doi:10.1111/j.1467-6419.2007.00527.x

Christiaensen L, Demery L, Kuhl J (2011) The (evolving) role of agriculture in poverty reduction: an empirical perspective. J Dev Econ 96(2):239-254, http://dx.doi.org/10.1016/j.jdeveco.2010.10.006

Cox G, Rampes H (2003) Adverse effects of khat: a review. Adv Psychiatr Treat 9(6):456-463. doi:10.1192/apt.9.6.456

Cunguara B, Darnhofer I (2011) Assessing the impact of improved agricultural technologies on household income in rural Mozambique. Food Policy 36(3):378-390, http://dx.doi.org/10.1016/j.foodpol.2011.03.002

Davis, R. S. (2008). Conditional Preemption, Commandeering, and the Values of Cooperative Federalism: An Analysis of Section 216 of EPAct. Columbia Law Review, 404-451. http://www.jstor.org/stable/40041761.

Dawson N, Martin A, Sikor T (2016) Green revolution in Sub-Saharan Africa: implications of imposed innovation for the wellbeing of rural smallholders. World Dev 78:204-218, http://dx.doi.org/10.1016/j.worlddev.2015.10.008

Di Falco S, Veronesi M, Yesuf M (2011) Does adaptation to climate change provide food security? A micro-perspective from Ethiopia. Am J Agric Econ 93(3):829-846. doi:10.1093/ajae/aar006

Diao X, Thurlow J, Benin S, Fan S (eds) (2012) Strategies and priorities for African agriculture: economywide perspectives from country studies. Strategies and priorities for African agriculture: economywide perspectives from country studies

Dorsey J, \& Assefa T (2005) Final evaluation report of Agricultural Cooperatives in Ethiopia (ACE) program activities. USAID. http://pdf.usaid.gov/pdf_docs/PDACG205.pdf. Accessed May 2016.

Dzanku FM, Jirström M, Marstorp H (2015) Yield gap-based poverty gaps in rural Sub-Saharan Africa. World Dev 67:336362, http://dx.doi.org/10.1016/j.worlddev.2014.10.030

Emana B (2009) Cooperatives: a path to economic and social empowerment in Ethiopia. International Labour Office. Coop AFRICA working paper, Number 9, Dares Salaam, http://lo.ch/public/english/employment/ent/coop/africa/ download/wpno9cooperativesinethiopia.pdf

Evenson RE, Gollin D (2003) Assessing the impact of the Green Revolution, 1960 to 2000. Science 300(5620):758-762. doi:10.1126/science.1078710

FCA (2015) Cooperative movement in Ethiopia: performances, challenges and intervention options. Annual bulletin report, Federal Cooperative Agency, Addis Ababa

FDRE (Federal Democratic Republic of Ethiopia) (1994) Agricultural cooperative societies. Proclamation No. 85/1994. Federal Negarit Gazeta, Addis Ababa

Fischer E, Qaim M (2012) Linking smallholders to markets: determinants and impacts of farmer collective action in Kenya. World Dev 40(6):1255-1268, http://dx.doi.org/10.1016/j.worlddev.2011.11.018

Francesconi, G. N., \& Heerink, N. (2010). Ethiopian Agricultural Cooperatives in an Era of Global Commodity Exchange: Does Organisational Form Matter? https://doi.org/10.1093/jae/ejq036

Francesconi GN, Heerink N (2011) Ethiopian agricultural cooperatives in an era of global commodity exchange: does organisational form matter? J Afr Econ 20(1):153-177. doi:10.1093/jae/ejq036

Francesconi, G. N., \& Ruben, R. (2012). The hidden impact of cooperative membership on quality management: A case study from the dairy belt of Addis Ababa. https://ssrn.com/abstract=2194296

Gebremedhin B, Jaleta M, Hoekstra D (2009) Smallholders, institutional services, and commercial transformation in Ethiopia. Agric Econ 40(1):773-787. doi:10.1111/j.1574-0862.2009.00414.x

Getahun TD, Villanger E (2015) Labor-intensive jobs for women and development: intrahousehold welfare effects and its transmission channels (No. 15). CMI (Chr. Michelsen Institute), Bergen, https://www.cmi.no/publications/file/ 5686-labor-intensive-jobs-for-women-and-development.pdf

Getnet K, Anullo T (2012) Agricultural cooperatives and rural livelihoods: evidence from Ethiopia. Ann Public Coop Econ 83(2):181-198. doi:10.1111/j.1467-8292.2012.00460.x

Hagos F, Mamo K (2014) Financial viability of groundwater irrigation and its impact on livelihoods of smallholder farmers: the case of eastern Ethiopia. Water Resour Econ 7:55-65, http://dx.doi.org/10.1016/j.wre.2014.08.001

Haughton JH \& Khandker SR (2009) Handbook on poverty and inequality. The World Bank

Hellin J, Lundy M, Meijer M (2009) Farmer organization, collective action and market access in Meso-America. Food Policy 34(1):16-22, http://dx.doi.org/10.1016/j.foodpol.2008.10.003

IFAD (International Fund for Agricultural Development) (2011) Rural poverty portal., http://www.ruralpovertyportal.org/ web/guest/region/home/tags/africa

Imbens G, Wooldridge JM (2009) Recent developments in the econometrics of program evaluation. J Econ Lit 47:5-86, https://doi.org/10.1257/jel.47.1.5

Ito J, Bao Z, Su Q (2012) Distributional effects of agricultural cooperatives in China: exclusion of smallholders and potential gains on participation. Food Policy 37(6):700-709, http://dx.doi.org/10.1016/j.foodpol.2012.07.009

Kassie M, Shiferaw B, Muricho G (2011) Agricultural technology, crop income, and poverty alleviation in Uganda. World Dev 39(10):1784-1795, http://dx.doi.org/10.1016/j.foodpol.2012.07.009

Kodama Y (2007) New role of cooperatives in Ethiopia: the case of Ethiopian coffee farmers' cooperatives. Afr Study Monogr 35:87-108, https://doi.org/10.14989/68489 
Leistritz, F. L., Bangsund, D. A., \& Hodur, N. M. (2004). Assessing the Economic Impact of Invasive Weeds: The Case of Leafy Spurge (Euphorbia esula) 1. Weed Technology, 18(sp1), 1392-1395. http://dx.doi.org/10.1614/0890-037X(2004)018[1392: ATEIOI]2.0.CO;2

Lemma T (2008) Growth without structures: the cooperative movement in Ethiopia. Cooperating out of poverty: the renaissance of the African cooperative movement. ILO, Geneva

Ma W, Abdulai A (2016) Does cooperative membership improve household welfare? Evidence from apple farmers in China. Food Policy 58:94-102, http://dx.doi.org/10.1016/j.foodpol.2015.12.002

Markelova H, Mwangi E (2010) Collective action for smallholder market access: evidence and implications for Africa. Rev Policy Res 27(5):621-640. doi:10.1111/j.1541-1338.2010.00462.x

Matsumoto T, Yamano T (2010) The Impacts of Fertilizer Credit on Crop Production and Income in Ethiopia (No. 10-23). National Graduate Institute for Policy Studies.

Matuschke I, Qaim M (2009) The impact of social networks on hybrid seed adoption in India. Agric Econ 40(5):493-505. doi:10.1111/j.1574-0862.2009.00393.x

Meyer BD \& Sullivan JX (2003) Measuring the well-being of the poor using income and consumption (No. w9760). National Bureau of Economic Research. http://www.nber.org/papers/w9760.pdf. Accessed May 2016.

Minten B, Barrett CB (2008) Agricultural technology, productivity, and poverty in Madagascar. World Dev 36(5):797-822, http://dx.doi.org/10.1016/j.worlddev.2007.05.004

MoA (Ministry of Agriculture) (2000) Agro-ecological zonations of Ethiopia. Ministry of Agriculture, Addis Ababa

Mojo D, Fischer C, Degefa T (2015) Social and environmental impacts of agricultural cooperatives: evidence from Ethiopia. Int J Sustain Dev World Ecol 22(5):388-400, http://dx.doi.org/10.1080/13504509.2015.1052860

Negatu B, Kromhout H, Mekonnen Y, Vermeulen R (2016) Use of chemical pesticides in Ethiopia: a cross-sectional comparative study on knowledge, attitude and practice of farmers and farm workers in three farming systems. Ann Occup Hyg 60(5):551-566. doi:10.1093/annhyg/mew004

OCDC (US Overseas Cooperative Development Council) (2007) Cooperatives: pathways to economic, democratic and social development in the global economy., http://www.electric.coop/wp-content/uploads/2016/07/Pathwayspaper.pdf

Pender J, Gebremedhin B (2007) Determinants of agricultural and land management practices and impacts on crop production and household income in the highlands of Tigray, Ethiopia. J Afr Econ 17(3):395-450. doi:10.1093/jae/ejm028

Poulton C, Dorward A, Kydd J (2010) The future of small farms: new directions for services, institutions, and intermediation. World Dev 38(10):1413-1428, http://dx.doi.org/10.1016/j.worlddev.2009.06.009

Rahmato D (1994) Land, peasants and the drive for collectivization in Ethiopia. In: Bassett TJ, Crummey DE (eds) Land in African agrarian system. University of Wisconsin Press, Madison, pp 274-297

Rosenbaum PR (2002) Observational studies. Springer, New York, pp 1-17. doi:10.1007/978-1-4757-3692-2_1

Rosenbaum PR, Rubin DB (1983) The central role of the propensity score in observational studies for causal effects. Biometrika 70(1):41-55, https://doi.org/10.1093/biomet/70.1.41

Shiferaw B, Kassie M, Jaleta M, Yirga C (2014) Adoption of improved wheat varieties and impacts on household food security in Ethiopia. Food Policy 44:272-284, http://dx.doi.org/10.1016/j.foodpol.2013.09.012

Simmons R, Birchall J (2008) The role of co-operatives in poverty reduction: network perspectives. J Socio-Econ 37(6): 2131-2140, http://dx.doi.org/10.1016/j.socec.2008.04.016

Spielman D (2008) Mobilizing rural institutions for sustainable livelihoods and equitable development: a case study of farmer cooperatives in Ethiopia: overview. Final Report, International Food Policy Research Institute, Washington DC

Spielman DJ, Byerlee D, Alemu D, Kelemework D (2010) Policies to promote cereal intensification in Ethiopia: the search for appropriate public and private roles. Food Policy 35(3):185-194, http://dx.doi.org/10.1016/.jfoodpol.2009.12.002

CSA (Central Statistical Agency) (2013) Population projection of Ethiopia for all regions at Wereda level from 2014-2017 Addis Ababa. http://www.csa.gov.et/images/general/news/pop_pro_wer_2014-2017_final. Accessed May 2016

Storck H, Emana B, Adnew B, Borowiccki A, Woldehawariat S (1991) Farming systems and resource economics in the tropics: farming system and farm management practices of smallholders in the Hararghe Highland, vol II. Wissenschaftsverlag Vauk, Kiel

Tefera DA, Bijman J \& Slingerland MA (2016) Agricultural co-operatives in Ethiopia: evolution, functions and impact. J Int Dev. doi: 10.1002/jid.3240

Thorp R, Stewart F, Heyer A (2005) When and how far is group formation a route out of chronic poverty? World Dev 33(6):907-920, http://dx.doi.org/10.1016/j.worlddev.2004.09.016

Timmer CP (1997) Farmers and markets: the political economy of new paradigms. Am J Agric Econ 79(2):621-627

Tittonell P, Giller KE (2013) When yield gaps are poverty traps: the paradigm of ecological intensification in African smallholder agriculture. Field Crop Res 143:76-90, http://dx.doi.org/10.1016/j.fcr.2012.10.007

Trebbin A (2014) Linking small farmers to modern retail through producer organizations-experiences with producer companies in India. Food Policy 45:35-44, http://dx.doi.org/10.1016/j.foodpol.2013.12.007

UN (United Nations) (2015) The Millennium Development Goals Report 2015. New York. http://www.un.org/ millenniumgoals/2015_MDG_Report/pdf/MDG\%202015\%20rev\%20(July\%201).pdf. Accessed May 2016.

UNDP (2015) African economic outlook: Ethiopia., http://www.africaneconomicoutlook.org/fileadmin/uploads/aeo/2015/ CN_data/CN_Long_EN/Ethiopia_GB_2015.pdf

Verhofstadt E, Maertens M (2014) Can agricultural cooperatives reduce poverty? Heterogeneous impact of cooperative membership on farmers' welfare in Rwanda. Appl Econ Perspect Policy 37(1):86-106. doi:10.1093/aepp/ppu021

Wanyama FO, Develtere P, Pollet I (2008) Encountering the evidence: cooperatives and poverty reduction in Africa. Working papers on social and co-operative entrepreneurship WP-SCE 08-02-2008., http://dx.doi.org/10.2139/ssm.1330387

Wanyama FO, Develtere P, Pollet I (2009) Reinventing the wheel? African cooperatives in a liberalized economic environment. Ann Public Coop Econ 80(3):361-392. doi:10.1111/j.1467-8292.2009.00390.x

Woldu T, Tadesse F \& Waller MK (2013) Women's participation in agricultural cooperatives in Ethiopia (No. 57). International Food Policy Research Institute (IFPRI). http://ageconsearch.umn.edu/bitstream/210967/2/AssefaWomen's\%20Participation\%20in\%20Agricultural\%20Cooperatives\%20in\%20Ethiopia-908.pdf. Accessed May 2016.

Zeng D, Alwang J, Norton GW, Shiferaw B, Jaleta M, Yirga C (2015) Ex post impacts of improved maize varieties on poverty in rural Ethiopia. Agric Econ 46(4):515-526. doi:10.1111/agec.12178 